\title{
Historical fire in the Appalachian Plateau of Ohio and Kentucky, USA, from remnant yellow pines
}

\author{
Todd F. Hutchinson ${ }^{1 *}$, Michael C. Stambaugh², Joseph M. Marschall ${ }^{2}$ and Richard P. Guyette ${ }^{2}$
}

\begin{abstract}
Background: Knowledge of historical fire regimes informs the restoration of woodland communities. In the Appalachian Plateau of Ohio and Kentucky, USA, little is known about the long-term history of fire in oak-pine communities, which are declining in the region. To address this knowledge gap, two sites with remnant fire-scarred yellow pines, Hatton Ridge in Kentucky and McAtee Run in Ohio, were studied to document aspects of the historical fire regime. Cross-sections from fire-scarred yellow pines were collected. Fire chronologies were constructed and fire intervals were calculated using standard dendrochronological methods.

Results: Fires, the great majority of which occurred in the dormant season, were frequent at both sites from circa 1750 at Hatton and 1800 at McAtee, until the suppression period (1930 to present); only one fire was recorded after 1930. Mean fire intervals (MFI) for the entire period were nearly identical, 4.7 and 4.4 years at Hatton and McAtee, respectively. At both sites, MFIs were lowest in the industrial period (1850 to 1930). At Hatton, the MFI was 6.6 years before 1850 and 3.5 years from 1850 to 1930, while at McAtee, the MFI was 8.4 years before 1850 and 2.7 years from 1850 to 1930. At both sites, the occurrence of fire was not more frequent than expected in years associated with a drought. At McAtee, the majority of pine establishment occurred in pulses during two periods, 1770 to 1781 and 1853 to 1867, suggesting stand-scale canopy disturbances; the second pulse was associated with frequent burning. In contrast, large pulses of pine establishment were not found at Hatton.

Conclusions: Yellow pines were a component of these communities, which experienced frequent fire for at least 130 to 160 years. After more than 70 years with little or no fire, yellow pines are now a minor component of the overstory and pine regeneration is essentially absent. Although intensive management with partial harvesting and frequent fire would be required to restore oak-pine woodlands on appropriate sites, it would serve to sustain these increasingly uncommon communities.
\end{abstract}

Keywords: Appalachian Plateau, dendrochronology, disturbance, fire history, Pinus echinata, Pinus rigida, oak-pine woodlands

\footnotetext{
*Correspondence: todd.hutchinson@usda.gov

'USDA Forest Service, Northern Research Station, 359 Main Road, Delaware,

Ohio 43015, USA

Full list of author information is available at the end of the article
} 


\section{Resumen}

Antecedentes: El conocimiento de los regímenes históricos de fuego nos ilustra sobre la restauración de comunidades de arbustos. En las planicies de los montes Apalaches de Ohio y Kentucky en los EEUU, muy poco se conoce sobre la historia del fuego a largo plazo en comunidades de roble y pino, que están declinando en esta región. Para enfocarnos en este vacío del conocimiento, dos sitios con escaras de fuego remanentes en pino amarillo, Hatton Ridge en Kentucky y McAtee Run en Ohio, fueron estudiados para documentar aspectos del régimen histórico de fuegos. Se colectaron secciones transversales (tortas) de pino amarillo. Las cronologías de fuego fueron reconstruidas y los intervalos de fuegos calculados usando métodos dendrocronológicos estándar.

Resultados: Los fuegos, la gran mayoría de los cuales ocurrieron en la estación de dormición, fueron frecuentes en ambos sitios desde circa 1750 en Hatton y en 1800 en McAtee, hasta el período de supresión de incendios (1930 al presente); un solo incendio fue registrado después de 1930. Los intervalos medios entre fuegos (MFI) para el período completo fue casi idéntico, 4.7 y 4.4 años para Hatton y McAtee, respectivamente. En ambos sitios, los MFls fueron menores durante en el período industrial (1850 a 1930). En Hatton, el MFI fue de 6.6 años antes de 1850 y de 3.5 años desde 1850 a 1930, mientras que en McAtee, el MFI fue de 8.4 años antes de 1850 y 2.7 años desde 1850 a 1930. En ambos sitios, la ocurrencia de fuegos no fue más frecuente que lo esperado en años de sequía. En McAtee, la mayoría del establecimiento de pinos ocurrió en pulsos durante dos períodos, de 1770 a 1781 y de 1853 a 1867, sugiriendo disturbios a gran escala en el dosel; el segundo pulso fue asociado a fuegos frecuentes. En contraste, estos largos pulsos de establecimiento de pinos no fueron encontrados en Hatton.

Conclusiones: Los pinos amarillos fueron un componente de esas comunidades, que experimentaron fuegos frecuentes por al menos 130 a 160 años. Después de más de 70 años sin fuegos o con muy pocos, los pinos amarillos son ahora un componente menor del dosel superior y su regeneración es esencialmente nula. Aunque el manejo intensivo con talas parciales y fuegos frecuentes puede ser requerido para restaurar comunidades de roble y pino en lugares apropiados, este puede servir también para mantener esas comunidades cada vez menos comunes.

\section{Introduction}

Fire is a key process that shapes vegetation structure and species composition in many ecosystems worldwide (Bond and Keeley 2005). In the temperate forest region of eastern North America, changes in forest structure and composition have been linked with the exclusion of periodic fire since the early to mid twentieth century (Brose et al. 2001; Lafon et al. 2017). Increasingly, prescribed fire is used to attempt to reverse these trends by creating more open structured forests and woodlands, increasing oak and pine regeneration, and improving habitat for declining wildlife species (Jenkins et al. 2011; Hutchinson et al. 2012; Harper et al. 2016; Lorber et al. 2018). Fire suppression has been hypothesized as the primary cause of the increasing abundance of mesophytic species in historically oak-dominated landscapes (Abrams 1992; Nowacki and Abrams 2008). However, others factors including precipitation shifts and dramatic land-use changes also are considered important (McEwan et al. 2011). Knowledge of fire regimes that sustained oak and pine ecosystems historically can provide managers with guidance on the use of prescribed fire in contemporary landscapes (Stambaugh et al. 2015). A lack of extensive fire history information that predates EuroAmerican settlement (EAS) has contributed in part to some criticism of the use of prescribed fire to manage Eastern forests (Matlack 2013); but see Stambaugh et al. (2015).

In the central Appalachian Plateau, a region dominated by mixed-oak forests, fire history research has analyzed fire scars formed in oaks in second-growth (e.g., Sutherland 1997; McEwan et al. 2007; Hutchinson et al. 2008) and oldgrowth stands (Shumway et al. 2001; McEwan et al. 2014). These studies found mean fire return intervals (MFIs) typically ranging from 6 to 12 years.

Despite the need for additional longer fire history chronologies in the region, it is difficult to obtain samples from old-growth oak stands. Because oaks decay rapidly in this region, only living or recently dead trees can be used for fire-scar analysis. Yellow pines (Pinus L. subgenus Diploxylon Koehne) such as shortleaf pine (Pinus echinata Mill.) and pitch pine (P. rigida Mill.) often decay slowly postmortem, particularly if wounded by fires that initiate the copious production of decayresistant resin. Thus, long-dead "remnant" yellow pines (trees, stumps, logs) can be recovered to develop longer fire histories, even in non-old-growth stands.

In the last decade, there have been a number of studies, primarily in the Ridge and Valley and Blue Ridge sections of the central and southern Appalachians, that have documented 300-year and longer fire histories from remnant (and living) yellow pines. These studies, reviewed in Lafon 
et al. (2017), showed that fire was historically frequent in pine and oak-pine stands (2- to 6-year MFI), with fire frequency often similar before and after EAS, and before and after the industrial logging period, until the fire suppression era. In addition, recent work in Ridge and Valley and Appalachian Plateau of central Pennsylvania, USA, provided further evidence of long-term (350+ year) frequent fire regimes in the Appalachians (Marschall et al. 2016; Stambaugh et al. 2018).

In the Appalachian Plateau, yellow pines are typically less common than in the Ridge and Valley and Blue Ridge provinces. In the southern Unglaciated Allegheny Plateau Section that includes southeastern Ohio, early land surveys (circa 1800) indicated that pines composed $<2 \%$ of witness trees (Dyer and Hutchinson 2019). However, in some areas, oak-pine stands were common on more xeric sites (e.g., Jones 1945). Yellow pines were more abundant in the northern Cumberland Plateau Section in Kentucky, supporting small- and large-scale pine tar production in the 1800s (Hockensmith and Ison 1996).

Throughout their ranges, shortleaf pine and pitch pine are declining in abundance and exhibit poor regeneration potential; fire suppression has been implicated as a primary cause (Moser et al. 2007; Stambaugh and Muzika 2007; South and Harper 2016). Both species have a suite of fire adaptations that include thick bark, root collar sprouting after topkill, improved seed germination on mineral soil or partial litter, and seedbeds and seedling establishment in high light or low competition environments (Lawson 1990, Little and Garrett 1990,). In long-unburned stands, thinning and repeated fires (Guldin 2007) or high-intensity fire (Jenkins et al. 2011; Black et al. 2018) have been shown to promote natural yellow pine regeneration.

In an attempt to better understand and lengthen the record of historical fire in the Appalachian Plateau, we located two sites with remnant fire-scarred pines for study, one in northern Kentucky and one in southern Ohio, USA. Our objective was to document aspects of the historical fire regime from fire scars formed in these remnant pines, including fire frequency, severity, seasonality, and the relationship of fire to drought. We also examined how the fire regime changed over time in response to human land use, and thus divided the chronology into three periods: (1) pre industrial (before 1850), (2) industrial (1850 to 1930), and (3) fire suppression (after 1930). In addition, we documented historic pine establishment and its relation to the fire regime.

\section{Methods}

\section{Study sites}

Contemporary wildfires occur predominantly in the spring (March to April) and fall (October to November) dormant seasons and are human caused (Haines et al.
1975; Yaussy and Sutherland 1994). In the central Appalachians, lighting-caused fires rarely occur during the peak spring and fall fire seasons, and are most likely to occur in the summer growing-season (June, July; Lafon et al. 2005). The number of fires is typically greater in the spring fire season, but, in the longer term, the area burned is greater in the fall season due to infrequent but more severe drought conditions that result in larger fires (Lafon et al. 2005; Maingi and Henry 2007).

The Hatton Ridge site $(37.883889,-83.695556)$ was located in Menifee County, Kentucky, in the Cumberland District of the Daniel Boone National Forest (Fig. 1). The site was situated on the western edge of the Northern Cumberland Plateau Section (McNab et al. 2007). The topography consisted of ridges capped by Pennsylvanian sandstone, with exposed cliffs, steep slopes, and narrow valleys. The ridgetop soils were well-drained Latham-Shelocta silt loams. The mean annual temperature was $12.5{ }^{\circ} \mathrm{C}$. Precipitation averaged $119 \mathrm{~cm}$ per year and was distributed evenly through the year, with monthly means ranging from $7.1 \mathrm{~cm}$ (October) to $12.2 \mathrm{~cm}$ (July) (https://www.usclimatedata.com/climate/ mount-sterling/kentucky/united-states/usky1176).

EuroAmerican settlement of the Bluegrass Region, located to the west of Hatton Ridge, began in the 1770s. Although there were no permanent Native American settlements in this region after circa 1750, it was used for hunting, and warfare with EuroAmerican settlers continued until the mid 1790s (Friend 2010). The rugged Cumberland Plateau remained sparsely populated throughout the nineteenth century, but large-scale industrial logging occurred in the late 1800 s and early 1900s (Williams 1989). In the 1930s, the landscape including Hatton Ridge became part of the Cumberland National Forest.

Current forests on the ridgetop adjacent to the cliff edge, where most fire-scarred pines were sampled, were dominated by chestnut oak (Quercus montana Willd.), scarlet oak (Q. coccinea Müenchh.), and shortleaf pine; other overstory species included black oak (Q. velutina Lam.), blackgum (Nyssa sylvatica Marshall), red maple (Acer rubrum L.), and Virginia pine (Pinus virginiana Mill.). Mountain laurel (Kalmia latifolia L.) and blueberries (Vaccinium L. spp.) were common understory shrubs.

The McAtee Run site (38.645, -83.178611) was in Scioto County, Ohio, within Shawnee State Forest, $2.5 \mathrm{~km}$ north of the Ohio River, and $100 \mathrm{~km}$ northeast of Hatton Ridge (Fig. 1). The McAtee site was within the Southern Unglaciated Allegheny Plateau Section (McNab et al. 2007). The topography was highly dissected with narrow ridges and steep slopes. Bedrock geology consisted of Mississippian sandstones and shales, and soils were predominantly Latham-Shelocta silt loam. Mean annual temperature was $12.7^{\circ} \mathrm{C}$. Precipitation averaged $104 \mathrm{~cm}$ per year and was 


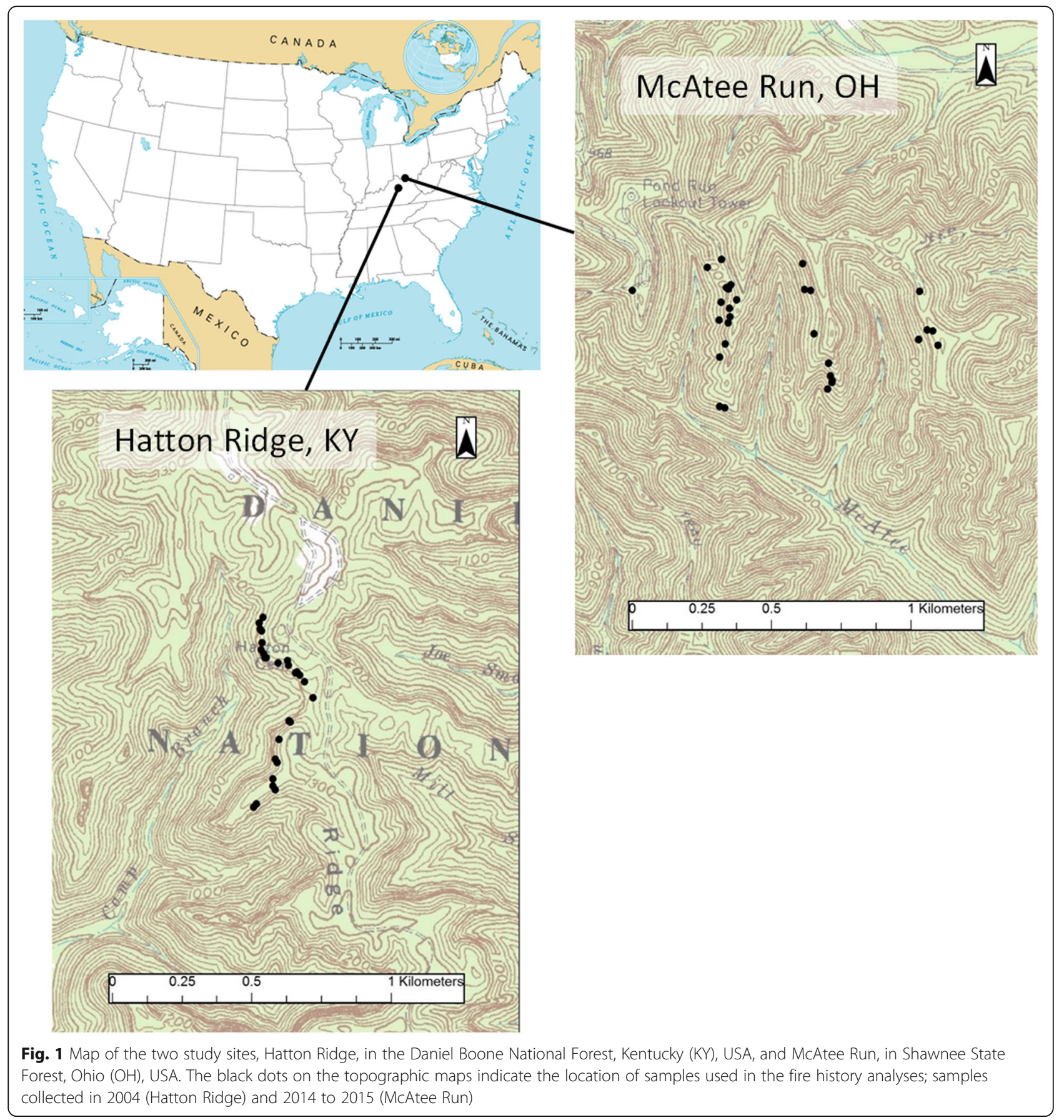

distributed evenly through the year, with monthly means ranging from $6.6 \mathrm{~cm}$ (October) to $12.5 \mathrm{~cm}$ (May) (https://www.usclimatedata.com/climate/ports mouth/ohio/united-states/usoh1954). Forest conditions at the time of EuroAmerican settlement, as described by Jones (1945), were oak dominated. However, oakpine stands, dominated by chestnut, black and scarlet oaks, pitch and shortleaf pines, were common on ridge-tops above $300 \mathrm{~m}$ elevation.
EuroAmerican settlement of Scioto County began in the late 1790s. However, the rugged landscape that now comprises the Shawnee State Forest (much of it in Nile Township) has remained mostly wooded. In 1885, it was estimated that only $17 \%$ of the land in Nile Township had been converted for cultivation or open pasture, but many of the forests had been logged, and fire and cattle grazing were reported as common in wooded areas (Leue 1886). Government land acquisition began in 
1922, and by 1933, most of the current Shawnee State Forest had been purchased. Organized fire suppression began in 1923 (Leete 1938).

On the ridges and upper west- and south-facing slopes where fire-scarred pine samples were collected, forests were dominated by chestnut oak, with black, scarlet, and white oak (Q. alba L.) as associates. Yellow pines, predominantly shortleaf pine, represent about $5 \%$ of overstory trees. Red maple, sourwood (Oxydendrum arboreum [L.] DC.), and blackgum are common in the understory, and dominant shrubs include greenbrier (Smilax rotundifolia L.) and blueberries. This site, as well as the Hatton Ridge site, appeared to be transitioning away from supporting yellow pines, based on the lack of regeneration and the abundance of hardwoods in the understory.

\section{Data collection and analysis}

In 2005, we searched the Hatton area for pine stumps and natural remnant wood exhibiting external evidence of fire scarring. The found samples were most likely shortleaf pine based on physical properties of the stumps and wood. Cross-sections were collected from 48 stumps and natural remnants using a chainsaw. The samples were located almost exclusively within $20 \mathrm{~m}$ of a cliff edge, along a $\sim 1 \mathrm{~km}$ stretch of Hatton Ridge (Fig. 1). Wood preservation was relatively poor, resulting in mostly small pieces of wood and, hence, short time periods represented in many of the stumps. Poor quality samples or samples that could not be crossdated were excluded; 31 samples were used in the fire history analyses. Although a number of individual samples recorded a limited number of years ( $<100$ years), together they produced a continuous record of rings from the mid 1700s forward. The majority of samples were collected from cut stumps.

Field sampling at McAtee occurred in 2014 and 2015. Although samples were collected from a larger area, here we use 30 samples from a $\sim 1 \mathrm{~km}^{2}$ area for fire history analyses (Fig. 1). Most samples in this area were located on several south- and west-facing slopes, although a few were on ridgetops. All of the remnant pines $(n=27)$ were natural snags. Cross-sections were also collected from three live trees.

In the laboratory, cross-sections were surfaced with an electric hand planer until the cellular detail of annual rings and fire scar injuries were revealed by sanding with progressively finer sandpaper (80 to 1200 grit). A radius (pith-to-bark) of the cross-section with the least amount of ring-width variability due to fire injuries was chosen for tree-ring measurement. Ring-width series from each sample were plotted and used for visual crossdating (Stokes and Smiley 1968). Samples were crossdated with a master dating chronology constructed from core samples collected from nearby living shortleaf pines. The COFECHA program (Holmes 1983; Grissino-Mayer 2001) was used to aid in absolute tree-ring dating and measurement quality control.

Once the pieces of wood were dated, we were able to assign calendar years to fire scar injuries. Fire-scar dates were assigned to the year of cambial response to wounding. When possible, fire scars were assigned to a season of year (Swetnam and Baisan 1996). Fire scars were identified by the presence of charcoal, callus tissue, traumatic resin canals, liquefaction of resin, and cambial injury; callus tissue and cambial injury were always present, while the other characteristics were usually but not always present. We used FHAES version 2.0.2 software (Brewer et al. 2015) to construct the fire chronology and calculate fire intervals and summary statistics for each site. Fire return intervals were derived from the composite fire scar chronologies and represented the occurrence of fire somewhere in the study areas. We calculated mean fire intervals (MFIs) and Weibull median intervals (WMIs; Brewer et al. 2015) from the composite fire-scar chronology of all fire years occurring at sites. The lower and upper exceedance intervals (LEIs, and UEIs; 95\% exceedance intervals) were also calculated, based on the probability distribution function (pdf) of a fitted Weibull distribution. We did not use the fire-recording concept in our analyses. The fire-recording concept is commonly used but has not been subjected to rigorous testing with respect to fire-scarring dynamics and ecology. Guyette et al. (2006) argued that not considering the period of record prior to an initial fire scar suggests that the tree was not susceptible to fire. This contradicts findings that smaller trees scar more easily (Gutsell and Johnson 1996; Guyette and Stambaugh 2004).

Fire-scar statistics were calculated for the entire period of record, starting with the first year in which three or more samples were present. We also calculated the individual tree or point fire return interval, which is the mean fire interval of all individual trees that have at least two fire scar dates. In addition, we calculated $10 \%$ and $25 \%$ filtered MFIs from fires that scarred $\geq 10 \%$ and $\geq 25 \%$ of samples. Fireinterval statistics were calculated for three time periods: (1) pre industrial, prior to 1850; (2), industrial, 1850 to1930; and (3) fire suppression, after 1930. Because the tree-ring records begin circa 1750, there was a relatively brief period of pre-EuroAmerican settlement (EAS), which was therefore included with the pre-industrial period. In the Appalachian region in general, the year 1850 has been noted as a transition to larger-scale industrial exploitation of forests, which included the use of railroads (Williams 1989; Lafon et al. 2017). In southern Ohio, forest clearance accelerated after 1850. The area of uncut forest in Scioto County, where the McAtee site was located, was estimated to have decreased from $78 \%$ in 1853 to $35 \%$ in 1881 (Leue 1886). 
To examine the relationship between fire occurrence and drought, we obtained reconstructed Palmer Drought Severity Index (PDSI) values from gridpoint 237, the closest to both study sties (Cook et al. 2004). We classified drought years as having a reconstructed PDSI of $\leq-2.0$, which includes moderate $(-2.0$ to -2.9$)$, severe $(-3.0$ to -3.9$)$, and extreme $(\leq-4.0)$ drought classes. We used a chi-square test $(2 \times 2$ contingency table) to determine whether fires were observed more frequently than expected in years associated with drought, compared to years not associated with drought. As nearly all fires were in the dormant season (October to April), a fire year (dated to the year of cambial response) occurred in association with a drought if either the year prior to or the year of the fire had a PDSI $\leq-2.0$.

We also documented periods of pine establishment from samples that had an intact pith. Because the crosssections were collected close to the ground, the pith dates should be within several years of seedling establishment. However, because both shortleaf and pitch pine can sprout from the root collar after being topkilled by fire or otherwise damaged, the rootstocks could have been older.

\section{Results}

Fires were recorded frequently at both sites from circa 1750 (Hatton) and 1800 (McAtee) until organized fire suppression became effective circa 1930. Although fire return intervals for the full period were nearly identical between the two sites, there were temporal differences in fire frequency and in the extent, severity, or both extent and severity of fire, based on the percentage of trees scarred. The two sites also exhibited contrasting pineestablishment dynamics, inferred from pith dates.

\section{Hatton Ridge, Kentucky: historical fire regime}

Thirty-eight fires were recorded at the Hatton site from 1753 to 1928 (Table 1, Fig. 2a). Although no fires were documented after 1928, the sample size became progressively smaller through the twentieth century. For the full period, fire intervals ranged from 1 to 21 years; the composite MFI was 4.7 years (Table 1). The composite MFI was 6.6 years in the pre-industrial period and 3.5 years in the industrial period. Scarring rates per fire were similarly low in both periods: $13.0 \%$ in the pre-industrial period and $12.0 \%$ in the industrial period, and only four fires $(1753,1839,1904,1910)$ had $\geq 25 \%$ of samples scarred. The $10 \%$ and $25 \%$ filtered MFIs for the full period were 9.7 and 52.3 years, respectively. The season of burn was determined in $85 \%$ of fire scars and, among those scars, $81.2 \%$ were formed in the dormant season, $15.6 \%$ were in the spring growing season (earlywood), and $3.1 \%$ in the summer (latewood).

The occurrence of fire at Hatton was not more frequent than expected in years associated with drought $\left(x^{2}\right.$ $=0.71, P=0.40, \mathrm{df}=1)$. During the pre-suppression era (1748 to 1930), $26 \%$ of all years were associated with drought in the previous or current year; for the 38 fire years, $32 \%$ occurred in years associated with drought. The 1839 fire, which was the only fire to scar $>25 \%$ of samples, occurred during a severe drought; reconstructed PDSIs were -2.7 in 1838 and -5.6 in 1839. For the two summer fires, the 1879 fire occurred in a

Table 1 Fire history statistics for the Hatton Ridge, Kentucky (HTN), and McAtee Run, Ohio (MAC), USA, study sites in four time periods. MFI = Mean fire interval, WMI = Weibull median interval. If there were $<2$ intervals for a period, then the mean fire interval or associated statistics are listed as "na" (not available)

\begin{tabular}{|c|c|c|c|c|c|c|c|c|}
\hline & \multicolumn{2}{|l|}{ Full period } & \multirow{2}{*}{\multicolumn{2}{|c|}{$\begin{array}{l}\text { Pre-industrial period } \\
\text { pre } 1850\end{array}$}} & \multirow{2}{*}{\multicolumn{2}{|c|}{$\frac{\text { Industrial period }}{1850-1930}$}} & \multirow{2}{*}{\multicolumn{2}{|c|}{$\frac{\text { Fire suppression period }}{1930 \text { - } \text { present }^{a}}$}} \\
\hline & \multirow{2}{*}{$\begin{array}{l}1748-2004 \\
\text { HTN }\end{array}$} & \multirow{2}{*}{$\begin{array}{l}1770-2014 \\
\text { MAC }\end{array}$} & & & & & & \\
\hline & & & HTN & MAC & HTN & MAC & HTN & MAC \\
\hline Number of scars & 75 & 182 & 26 & 6 & 49 & 169 & 0 & 7 \\
\hline Number of fire years & 38 & 34 & 15 & 6 & 23 & 28 & 0 & 1 \\
\hline MFI (years) & 4.7 & 4.4 & 6.6 & 8.4 & 3.5 & 2.7 & na & na \\
\hline Standard deviation & 4.3 & 4.5 & 6.2 & 5.3 & 1.9 & 1.7 & na & na \\
\hline Interval range (years) & 1 to 21 & 1 to 16 & 1 to 21 & 2 to 16 & 1 to 8 & 1 to 8 & na & na \\
\hline WMI (years) & 3.9 & 3.4 & 5.2 & 7.7 & 3.3 & 2.5 & na & na \\
\hline Lower exceedance interval & 1.1 & 0.8 & 1.3 & 3.1 & 1.4 & 1.0 & na & na \\
\hline Upper exceedance interval & 9.1 & 8.8 & 13.0 & 14.1 & 5.7 & 4.6 & na & na \\
\hline Mean scarred (\%) & 12.5 & 21.1 & 13.0 & 8.7 & 12.0 & 23.3 & na & 36.8 \\
\hline $10 \%$ filtered MFI (years) & 9.7 & 5.2 & 12.3 & na & 5.3 & 3.9 & na & na \\
\hline 25\% filtered MFI (years) & 52.3 & 6.3 & na & na & na & 5.7 & na & na \\
\hline Individual tree MFI (years) & 15.4 & 8.4 & 18.9 & 11.0 & 10.4 & 7.5 & na & 25.0 \\
\hline
\end{tabular}

${ }^{\mathrm{a}} 2004$ and 2014 for Hatton Ridge and McAtee Run, respectively 
a)

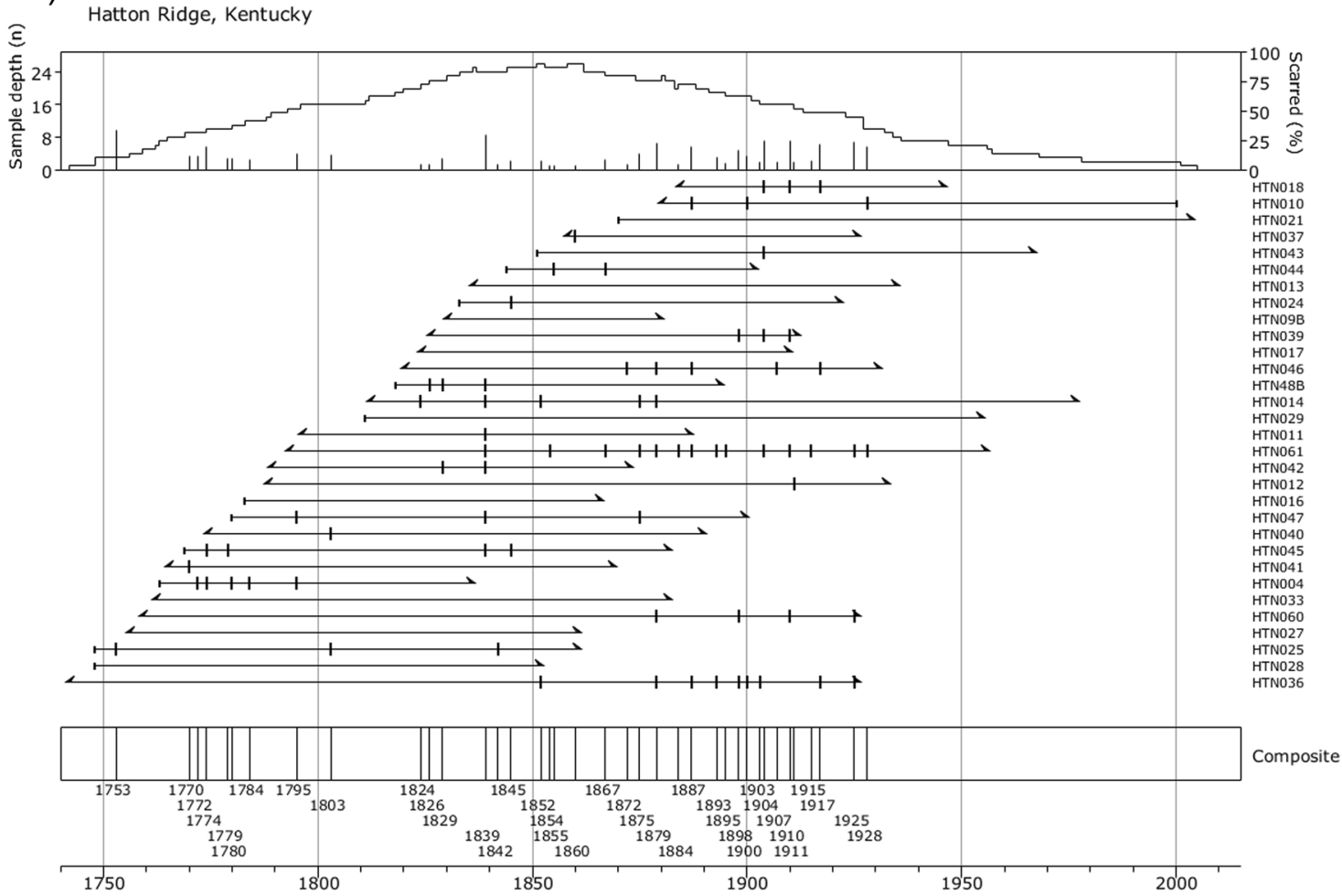

b)

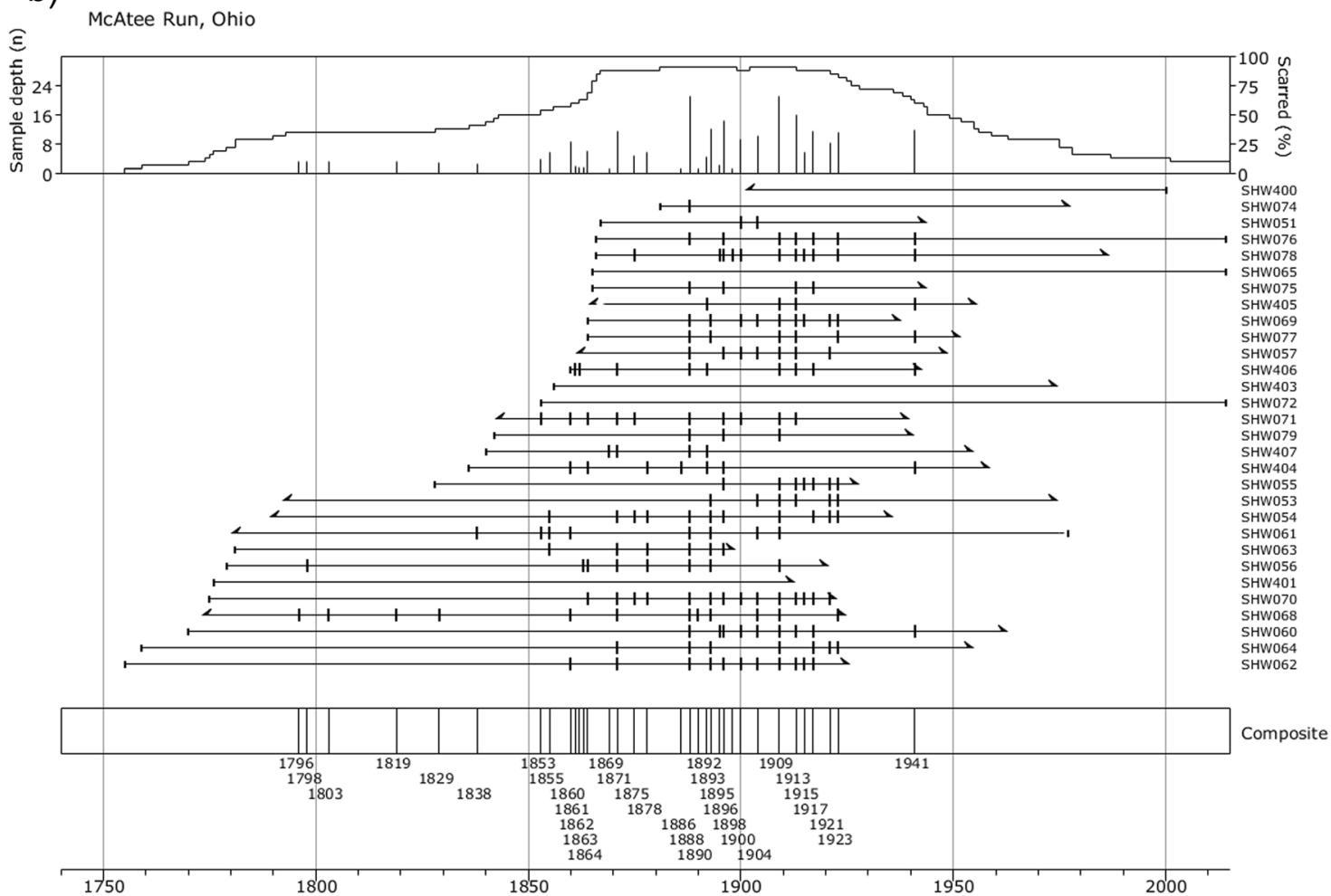

Fig. 2 (See legend on next page.) 
(See figure on previous page.)

Fig. 2 Fire-scar diagrams for (a) Hatton Ridge, Kentucky, USA, and (b) McAtee Run, Ohio, USA. Each horizontal line represents the years covered by an individual tree (sample number on right). The vertical lines along the timeline of each sample are fire-scar years. Slanted or vertical lines at the earliest year for each sample indicate either the innermost ring or pith date, respectively. For the last year recorded, a slanted line is the outermost ring present, while a vertical line indicates the outermost ring with bark present. The vertical lines on the composite axis indicate years in which one or more sample had a fire scar across the entire site. Samples were collected in 2004 (Hatton Ridge) and 2014 to 2015 (McAtee Run)

drought year (PDSI -3.0) but the 1904 fire did not (PDSI 0.8).

\section{McAtee Run, Ohio: historical fire regime}

Thirty-three fires were documented at the McAtee site in the pre-suppression era, from 1796 to 1923 (Table 1, Fig. 2b). An additional fire occurred in the early part of the suppression era, in 1941. For the full period, fire intervals ranged from 1 to 18 years; the MFI was 4.4 years (Table 1). In contrast to Hatton, the McAtee site exhibited a relatively long period without recorded fires scars in the earliest portion of the chronology, from 1770 (first year with three samples) to 1795, which were the last few decades of the pre-EAS period. There were only six fires recorded in the pre-industrial period (MFI $=8.4$ years), compared to 27 fires documented in the industrial period prior to fire suppression $(\mathrm{MFI}=2.7$ years; Table 1$)$. Overall, an average of $21.0 \%$ of samples were scarred per fire. Scarring rates were low in the pre-industrial period, as each of the six fire years had only a single fire-scarred tree, a mean of 8.7\% scarred per fire. In contrast, 169 scars were recorded in the 27 fire years in the industrial period, a mean 23.3\% of trees scarred per fire. For the full period, the $10 \%$ and 25\% filtered composite MFIs were 5.2 and 6.3 years, respectively. The season of burn was determined in $92 \%$ of the fire scars; among those, scars were formed almost exclusively (98.8\%) in the dormant season.

Similar to the Hatton site, fires at McAtee were not significantly associated with drought $\left(\chi^{2}=0.09, P=0.77\right.$, $\mathrm{df}=1$ ). In the pre-suppression era, from 1771 to 1930 , $23 \%$ of all years were associated with drought and only $21 \%$ of fire years were associated with drought. For the 12 fires that scarred $>25 \%$ of samples, only two (1888 and 1895) were associated with droughts and the single summer (latewood) fire, recorded in 1829, did not occur during a drought $(\mathrm{PDSI}=-0.39)$.

\section{Historic pine establishment}

At Hatton Ridge, intact piths were present in only 12 samples. These pith dates, although limited, recorded periodic pine establishment from the 1740 s to the 1870 s without any large pulses (Fig. 3a); this pattern suggests primarily small-scale rather than stand-scale pine recruitment. There was no apparent association between fire frequency (fires per decade) and pine establishment.

At McAtee, more samples $(n=22)$ had an intact pith. In contrast to Hatton, there were two large pulses of pine establishment: 1770 to 1781 (five trees), and 1853 to 1867 (10 trees); nearly 70\% of the recorded pine establishment was during these two periods (Fig. 3b). In both periods, pine establishment, from the georeferenced samples, was documented throughout much of the $1 \mathrm{~km}^{2}$ study site. After the pulse of pine establishment in the 1770s, no further establishment was recorded for nearly 50 years, until 1828 .

Before and during the first pulse of pine establishment (1770s), no fires were documented, although the sample size was small ( 3 to 9 trees) and could be limited in firerecording potential. In contrast, the $1850 \mathrm{~s}$ - to $1860 \mathrm{~s}$ establishment pulse followed a period of frequent fire. Annual burning was recorded from 1860 to 1864, and seven trees had pith dates of 1864 to 1867 (Fig. 3b). After this second pulse, the only documented pine establishment was a single tree with a pith date of 1881 . No pine establishment was recorded during the 35-year period, 1888 to 1923, when fires were frequent and scarring rates were greater, averaging $31 \%$.

\section{Discussion}

For the portion of the Appalachian Plateau that includes the southern Allegheny and northern Cumberland Plateau Sections, this study provides new details of fire history in forests with a yellow pine component. The fire history includes the pre-industrial period (prior to 1850), and also a limited period when the Shawnee and other Native American Nations were present on the landscape prior to widespread EuroAmerican settlement. At both sites, fire was frequent before the suppression era and the MFIs of 4.4 years (McAtee) and 4.7 years (Hatton) are within the two to six year range that has been reported from sites with yellow pines in the central and southern Appalachians (Hoss et al. 2008; Aldrich et al. 2010; Flatley et al. 2013; Stambaugh et al. 2018). Also similar is that the great majority of fires occurred in the dormant season, when lightning is uncommon (suggesting human ignition source), and fire occurrence was not significantly related to drought conditions.

One objective of this research was to obtain information on the fire regime pre-EAS. In central and eastern Kentucky, there were few Native American settlements throughout the 1700s, although the area was used for hunting by the Shawnee and other Nations (Friend 2010). At Hatton, the earliest recorded fire was in 1753, prior to EAS. Fires occurred regularly from 1770 to 1784 


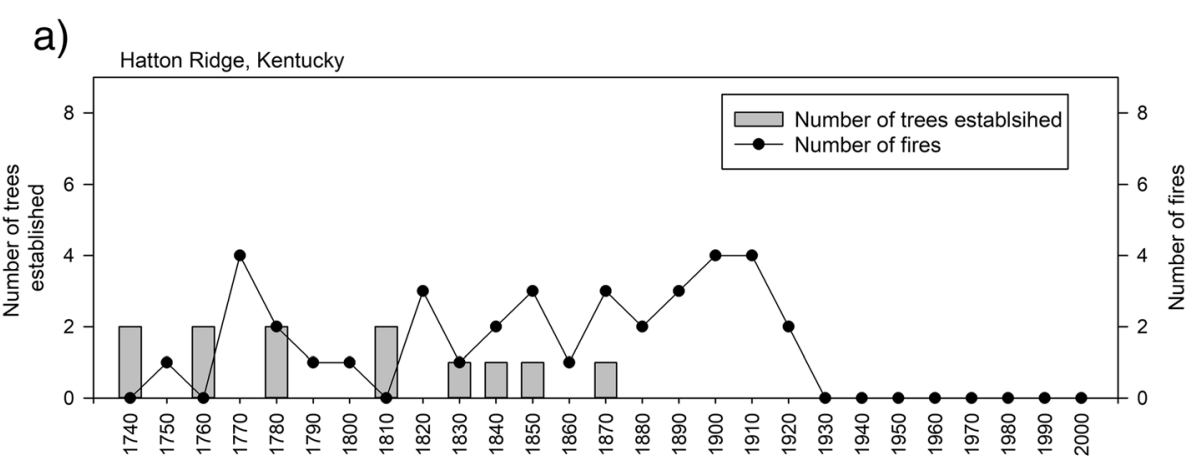

b)

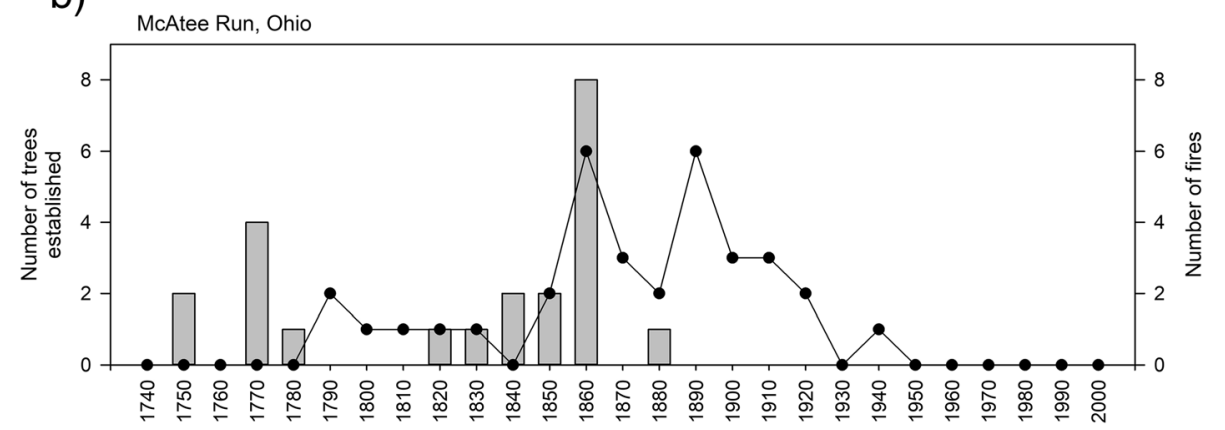

Fig. 3 The number of fires per decade and the number of yellow pines with pith dates per decade at (a) Hatton Ridge, Kentucky, USA (1748 to 2004), and (b) McAtee Run, Ohio, USA (1770 to 2014)

when EuroAmerican settlements, enclosed within forts, were being established in the nearby Bluegrass Region (Friend 2010). Settlement progressed sporadically as the Shawnee living north of the Ohio River often raided the settlements. This period of frequent fire at Hatton occurred during a period of transition and conflict. The earliest recorded fires at the McAtee site in Ohio (1796 and 1798) occurred during the early EAS period, soon after the Treaty of Greenville (1795) removed Native Americans to northern Ohio (Hurt 1998). Although no fires were documented before 1796, the sample size was quite small, likely limiting our ability to detect fires, particularly fires that did not burn through the entire site or were low intensity.

Understanding the historical fire regimes and the associated forest conditions is of broad interest, especially with regard to the pre-EAS period. To this end, two conceptual models have been proposed for the history of fire in the Appalachians and other areas where mixedoak and oak-pine forests are dominant. First, Brose et al. (2001) described a long period, circa 1600 to 1850, that spanned the pre-EAS and pre-industrial EAS periods, when fire frequency and severity were low to moderate. Their model shows that fire frequency and severity then increased sharply during the industrial logging period that began after 1850 and peaked in the late 1800 s and early 1900s. Thereafter, fire was essentially absent during the suppression era. This model of increased fire after EAS has been supported by recent research in the Ridge and Valley and Appalachian Plateau of Pennsylvania by Stambaugh et al. (2018), who found a consistent increase in fire frequency (i.e., a "wave of fire" soon after EAS, which persisted until the suppression era). Although the McAtee site has limited data on the pre-EAS period, it does fit the Brose model and the findings of Stambaugh et al. (2018) with respect to more frequent fire during the industrial period. The MFI was 8.4 years before 1850 and 2.7 years after 1850 and the percentage of samples scarred was also greater after 1850, especially from circa 1885 to 1925 .

An alternative model of Appalachian fire history, based on study sites in the Ridge and Valley and Blue Ridge provinces of Virginia and North Carolina, USA, was proposed by Lafon et al. (2017). Their model posited that fire occurred frequently throughout the pre-EAS period, and remained so through the preindustrial and industrial EAS periods, until a sharp decline in the suppression era. In our study, the Hatton site exhibited some elements of both models. The MFI was 6.6 years before 1850 and 3.5 years after 1850 , but scarring rates, which infer fire severity, were similarly low in both periods. It seems likely that either model may apply to a landscape or region, depending on the topographic setting, environmental conditions, and vegetation, as well as human population, land use, and culture, which largely drive 
ignitions and thus fire occurrence in anthropogenic fire regimes (Guyette et al. 2002).

While these two study sites show frequent fire (MFI $<5$ years) in oak-pine forests in the pre-suppression period, the relatively small sample sizes could result in an overestimation of the MFI. This is particularly true during the early (pre-1800) and late (post-1930) periods: at Hatton Ridge, $<10$ samples represent the periods before 1774 and after 1931; at McAtee the sample size is $<10$ before 1790 and after 1962. Van Horne and Fulé (2006) conducted a complete census of fire-scarred trees in a $1 \mathrm{~km}^{2}$ ponderosa pine site in Arizona, USA, and found that, when there were $<40$ targeted samples (collected because of multiple scars and long records), the MFI was overestimated, although not greatly. Although we were able to use 31 and 30 cross-dated samples in this study, the relatively poor wood preservation limited the sample replication within years. The mean number of dateable years per sample was 109 at Hatton Ridge and 126 at McAtee Run. Differences in the MFIs between the pre-industrial and industrial periods may have been partly due to sample size differences, particularly at the McAtee Run site. In the pre-industrial period (1771 to 1849), the MFI interval was 8.4 years and the sample size ranged from 3 to 16 . In contrast, the MFI was only 2.7 years in the industrial period (1850 to 1930), but sample sizes were also larger, ranging from 16 to 29 , and for the great majority of that period (1866 to 1925), sample size was $\geq 25$.

In the Appalachians, studies of the age structure of yellow pines suggest that, historically, regeneration occurred at both the small scale (gap or patch), producing uneven-aged stands, and after stand-scale canopy disturbance (e.g., stand-replacement fire, clearcut harvest), producing even-aged stands (Brose and Waldrop 2006; Aldrich et al. 2010; Flatley et al. 2013). At Hatton Ridge, stand-scale pine establishment pulses were not documented, but data were limited because so few samples had intact piths. Throughout pre-industrial and industrial periods, scarring rates at Hatton Ridge were quite low compared to other studies (Aldrich et al. 2010; Flatley et al. 2013; Stambaugh et al. 2018), suggesting that fires at this site were low intensity and perhaps not contiguous across the site. This may be due to the topographic setting, which is on a relatively broad and flat ridgetop. Nearly all of the remnant pine samples were collected within $30 \mathrm{~m}$ of a cliff edge that likely prevented the upslope spread of fire from below (Fig. 1). Prescribed fires ignited on similar ridgetops in the Cumberland Plateau have been low intensity (Blankenship and Arthur 2006), although high-severity fire can occur in drought conditions (Black et al. 2018). Also, because we calculated scarring rates based on all samples present, regardless of their recorder status, our scarring rate estimates were lower than in studies that used only recorder trees to calculate the percentage of samples scarred.

In contrast, the McAtee Run site had two stand-wide pulses of pine regeneration, during the periods 1770 to 1781 and 1856 to 1867 , suggesting that regeneration followed canopy disturbances that affected much of the $1 \mathrm{~km}^{2}$ site. For the 1770s pine establishment event, there were only two samples with rings that pre-dated this period, neither of which had fire scars. The 1850s- to 1860s-pine-establishment pulse at McAtee occurred at the onset of the industrial period when logging rates increased. However, this was also a period of frequent fire: annual burning occurred at McAtee from 1860 to 1864 . The majority of the pine pith dates $(n=7)$ were 1865 to 1868 , a fire-free period that followed the annual burning. One curious aspect of pine establishment at McAtee is that none was documented after 1881; the nearly 50 year period from then until the suppression era was characterized by frequent fires and greater scarring rates. It seems unlikely that fire was too frequent or severe for pine recruitment (see Stambaugh et al. 2007). One possibility is that open grazing during this period may have limited pine establishment. In an 1886 report on the status of the forests in Nile Township, where the McAtee site is located, Reverend J.G. Hall noted that, "Cattle allowed a free range through eight or ten miles of forests and abandoned fields, keep down the growth somewhat" (Leue 1886). Also, our field sampling focused on the collection of older fire-scarred pines, which limited our ability to detect more recent (e.g., after 1881) establishment.

In contemporary forests, the combination of partial harvest and prescribed fire, in a woodland restoration context, has been shown to facilitate shortleaf pine regeneration in the western portion of the Central Hardwoods region, in the Ozark and Ouachita mountains (Clabo et al. 2016; Olson and Olson 2016). In the Appalachians, without partial harvest, moderate- to high-severity prescribed fire has been required to initiate yellow pine regeneration in long-unburned stands (Waldrop and Brose 1999; Jenkins et al. 2011). Yellow pines were a component of these stands that experienced frequent fire for at least $\sim 130$ years (McAtee) to $\sim 160$ years (Hatton). Today, after a $>70$-year fire-free period, shortleaf and pitch pines are a relatively minor component of the overstory, especially at the McAtee site, and pine regeneration is essentially absent. On these sites, restoration to more open conditions with a significant pine component would require intensive management with mechanical thinning and frequent fire (Olson and Olson 2016), perhaps supplemented with planting. However, restoring open oak-pine woodlands on appropriate sites would serve to sustain a community that is in decline throughout the region and increase community diversity on the landscape. 


\section{Conclusion}

The 250 -year historical fire regimes documented at these two sites in the Appalachian Plateau are broadly similar to other Appalachian sites with a yellow pine component (Lafon et al. 2017; Stambaugh et al. 2018). Fires were frequent ( $<5$-year MFI) until the suppression era; largely occurred in the dormant season (suggesting anthropogenic ignition); and were not more frequent during drought conditions, as indicated by PDSI. At both sites, MFIs were $\geq 6.5$ years in the pre-industrial period (before 1850) and $\leq 3.5$ years in the industrial period (1850 to 1930). At the McAtee site, historic pine establishment occurred primarily in two pulses in the 1770 s and 1860s, suggesting stand-scale canopy disturbances; at the Hatton site, large pulses of pine establishment were not documented. This study adds to the growing body of evidence that historic frequent fire was an integral process that sustained oak-pine communities in the Appalachians. Throughout much of their ranges, shortleaf and pitch pines are declining in abundance and exhibit poor regeneration potential, highlighting the need for intensive management that includes frequent fire on appropriate sites with good restoration potential.

\section{Acknowledgments}

We thank the USDA Forest Service; Daniel Boone National Forest; and the Ohio Department of Natural Resources, Division of Forestry, for permission to conduct this research and for providing logistical support. Field and laboratory assistance was provided by E. Abadir, D.M. Bourscheidt, and T, Fox. We thank D. Dey and R. McEwan and two anonymous reviewers for helpful suggestions on previous drafts of this manuscript.

\section{Author's contributions}

TFH, MCS, RPG, and JMM all conceived this study. MCS and JMM oversaw the dendrochronology laboratory work. TFH and MCS did the data analysis and writing. TFH, MCS, RPG, and JMM read and approved the final manuscript.

\section{Funding}

This research was supported by the US Forest Service, Northern Research Station, and the Joint Fire Science Program Project \# 06-3-1-16.

\section{Availability of data and materials}

Data available from authors upon reasonable request.

\section{Ethics approval and consent to participate}

Not applicable.

\section{Consent for publication}

Not applicable.

\section{Competing interests}

The authors declare that they have no competing interests.

\section{Author details}

${ }^{1}$ USDA Forest Service, Northern Research Station, 359 Main Road, Delaware, Ohio 43015, USA. ${ }^{2}$ Missouri Tree-Ring Laboratory, School of Natural Resources, University of Missouri, 203C Anheuser-Busch Natural Resources Building, Columbia, Missouri 65211, USA.
Received: 19 February 2019 Accepted: 8 August 2019

Published online: 18 September 2019

\section{References}

Abrams, M.D. 1992. Fire and the development of oak forests. Bioscience 42: 346353. https://doi.org/10.2307/1311781.

Aldrich, S.R., C.W. Lafon, H.D. Grissino-Mayer, G.G. DeWeese, and J.A. Hoss. 2010. Three centuries of fire in montane pine-oak stands on a temperate forest landscape. Applied Vegetation Science 13: 36-46. https://doi.org/10.1111/ j.1654-109X.2009.01047.X.

Black, D.E., Z.W. Poynter, C.A. Cotton, S. Upadhaya, D.D. Taylor, W. Leuenberger, B. A. Blankenship, and M.A. Arthur. 2018. Post-wildfire recovery of an upland oak-pine forest on the Cumberland Plateau, Kentucky, USA. Fire Ecology 14 (14). https://doi.org/10.1186/s42408-018-0013-9.

Blankenship, B.A., and M.A. Arthur. 2006. Stand structure over 9 years in burned and fire-excluded oak stands on the Cumberland Plateau, Kentucky. Forest Ecology and Management 225: 134-145. https://doi.org/10.1016/j.foreco.2 005.12.032.

Bond, W.J., and J.E. Keeley. 2005. Fire as a global 'herbivore': the ecology and evolution of flammable ecosystems. Trends in Ecology \& Evolution 20: 387394. https://doi.org/10.1016/j.tree.2005.04.025.

Brewer, P., M. Velásquez, E. Sutherland, and D. Falk. 2015. Fire History Analysis and Exploration System (FHAES) version 2.0.2. http://www.frames.gov/fhaes/home Accessed 2 Aug 2019.

Brose, P., T. Schuler, D. Van Lear, and J. Berst. 2001. Bringing fire back: the changing regimes of the Appalachian mixed-oak forests. Journal of Forestry 99: 30-35.

Brose, P.H., and T.A. Waldrop. 2006. Fire and the origin of Table Mountain pine - pitch pine communities in the southern Appalachian Mountains, USA. Canadian Journal of Forest Research 36: 710-718. https://doi.org/10.1139/×05-281.

Clabo, D.C., J.M. Guldin, and W.K. Clatterbuck. 2016. Age and size comparisons of regenerating shortleaf pine seedlings burned multiple times in ecosystem restoration areas. In: Proceedings of the 18th Biennial Southern Silvicultural Research Conference. USDA Forest Service General Technical Report SRS-212, ed. C.J. Schweitzer, W.K. Clatterbuck, and C.M. Oswalt, 422-428. Asheville: USDA Forest Service, Southern Research Station.

Cook, E.R., D.M. Meko, D.W. Stahle, and M.K. Cleaveland. 2004. North American summer PDSI reconstructions. World Data Center for Paleoclimatology Data, contribution series \#2004-045. http://www.ncdc.noaa.gov/paleo/newpdsi. html. Accessed Jul 2017.

Dyer, J.M., and T.F. Hutchinson. 2019. Topography and soils-based mapping reveals fine-scale compositional shifts over two centuries within a central Appalachian landscape. Forest Ecology and Management 433: 33-42. https:// doi.org/10.1016/j.foreco.2018.10.052.

Flatley, W.T., C.W. Lafon, H.D. Grissino-Mayer, and L.B. LaForest. 2013. Fire history, related to climate and land use in three southern Appalachian landscapes in the eastern United States. Ecological Applications 23: 1250-1266. https://doi. org/10.1890/12-1752.1.

Friend, C.T. 2010. Kentucke's frontiers. Bloomington: Indiana University Press.

Grissino-Mayer, H.D. 2001. Evaluating crossdating accuracy: a manual and tutorial for the computer program COFECHA. Tree-Ring Research 57: 205-221.

Guldin, J.M. 2007. Restoration and management of shortleaf pine in pure and mixed stands - science, empirical observation, and the wishful application of generalities. In: Shortleaf pine restoration and ecology in the Ozarks: proceedings of a symposium. USDA Forest Service General Technical Report NRS-P-15. J.M. Kabrick, D.C. Dey, D. Gwaze. ed. 47-58. Newtown Square: USDA Forest Service, Northern Research Station.

Gutsell, S.L., and E.A. Johnson. 1996. How fire scars are formed: coupling a disturbance process to its ecological effect. Canadian Journal of Forest Research 26: 166-174. https://doi.org/10.1139/x26-020.

Guyette, R.P., R.-M. Muzika, and D.C. Dey. 2002. Dynamics of an anthropogenic fire regime. Ecosystems 5: 472-486.

Guyette, R.P., M.A. Spetich, and M.C. Stambaugh. 2006. Historic fire regime dynamics and forcing factors in the Boston Mountains, Arkansas, USA. Forest Ecology and Management 234: 293-304. https://doi.org/10.1016/j.foreco.2006.07.016.

Guyette, R.P., and M.C. Stambaugh. 2004. Post-oak fire scars as a function of diameter, growth, and tree age. Forest Ecology and Management 198: 183192. https://doi.org/10.1016/j.foreco.2004.04.016.

Haines, D.A., V.J. Johnson, and W.A. Main. 1975. Wildfire atlas of the northeastern and north central states. USDA Forest Service General Technical Report NC16. St. Paul: USDA Forest Service, North Central Forest Experiment Station. 
Harper, C.A., W.M. Ford, M.A. Lashley, C.E. Moorman, and M.C. Stambaugh. 2016. Fire effects on wildlife in the Central Hardwoods and Appalachian regions. Fire Ecology 12: 127-159. https://doi.org/10.4996/fireecology.1202127.

Hockensmith, C.D., and C.R. Ison. 1996. Kentucky's historic pine tar industry: comparisons between large and small scale technologies. West Virginia Archeologist 48: 1-18.

Holmes, R.L. 1983. Computer-assisted quality control in tree-ring dating and measurement. Tree-Ring Bulletin 43: 69-78.

Hoss, J.A., C.W. Lafon, H.D. Grissino-Mayer, S.R. Aldrich, and G.G. DeWeese. 2008. Fire history of a temperate forest with an endemic fire-dependent herb. Physical Geography 29: 424-441. https://doi.org/10.2747/0272-3646.29.5.424.

Hurt, R.D. 1998. The Ohio frontier: crucible of the old Northwest, 1720-1830. Bloomington: Indiana University Press.

Hutchinson, T.F., R.P. Long, R.D. Ford, and E.K. Sutherland. 2008. Fire history and the establishment of oaks and maples in second-growth forests. Canadian Journal of Forest Research 38: 1184-1198. https://doi.org/10.1139/X07-216.

Hutchinson, T.F., R.P. Long, J. Rebbeck, E.K. Sutherland, and D.A. Yaussy. 2012. Repeated prescribed fires alter gap-phase regeneration in mixed-oak forests. Canadian Journal of Forest Research 42: 303-314. https:/doi.org/10.1139/X11-184

Jenkins, M.A., R.N. Klein, and V.L. McDaniel. 2011. Yellow pine regeneration as a function of fire severity and post-burn stand structure in the southern Appalachian Mountains. Forest Ecology and Management 262: 681-691. https://doi.org/10.1016/j.foreco.2011.05.001

Jones, C.H. 1945. Vegetation of the Adams-Scioto quadrangle. Dissertation, Ohio State University, Columbus, Ohio, USA

Lafon, C.W., J.A. Hoss, and H.D. Grissino-Mayer. 2005. The contemporary fire regime of the central Appalachian Mountains and its relation to climate. Physical Geography 26: 126-146. https://doi.org/10.2747/0272-3646.26.2.126.

Lafon, C.W., A.T. Naito, H.D. Grissino-Mayer, S.P. Horn, and T.A. Waldrop. 2017. Fire history of the Appalachian region: a review and synthesis. USDA Forest Service General Technical Report SRS-219. Asheville: USDA Forest Service, Southern Research Station

Lawson, E.R. 1990. Pinus echinata Mill. Shortleaf pine. In: Silvics of North America. Volume 1, conifers. Agricultural handbook 654, ed. R.M. Burns and B.H. Honkala, 316-326. Washington, D.C.: USDA Forest Service.

Leete, B.E. 1938. Forest fires in Ohio: 1923 to 1935. Bulletin 598. Wooster: Ohio Agricultural Experiment Station.

Leue, A. 1886. First annual report of the Ohio State Forestry Bureau: for the year 1885. Columbus: Wesbote County, state printers.

Little, S., and P.W. Garrett. 1990. Pinus rigida Mill. Pitch pine. In Silvics of North America. Volume 1, conifers. Agricultural handbook 654, ed. R.M. Burns and B.H. Honkala, 456-462. Washington, D.C.: USDA Forest Service.

Lorber, J., M. Thomas-Van Gundy, and S. Croy. 2018. Characterizing effects of prescribed fire on forest canopy cover in the George Washington and Jefferson national forests. USDA Forest Service Research Paper NRS-31. Newtown Square: USDA Forest Service, Northern Research Station. https://doi.org/10.2737/NRS-RP-31.

Maingi, J.K., and M.C. Henry. 2007. Factors influencing wildfire occurrence and distribution in eastern Kentucky, USA. International Journal of Wildland Fire 16 23-33. https://doi.org/10.1071/WF06007.

Marschall, J.M., M.C. Stambaugh, B.C. Jones, R.P. Guyette, P.H. Brose, and D.C. Dey. 2016. Fire regimes of remnant pitch pine communities in the Ridge and Valley region of central Pennsylvania, USA. Forests 7: 224. https://doi.org/1 0.3390/f7100224.

Matlack, G.R. 2013. Reassessment of the use of fire as a management tool in deciduous forests of eastern North America. Conservation Biology 27: 916 926. https://doi.org/10.1111/cobi.12121

McEwan, R.W., J.M. Dyer, and N. Pederson. 2011. Multiple interacting ecosystem drivers: toward an encompassing hypothesis of oak forest dynamics across eastern North America. Ecography 34: 244-256. https://doi.org/10.1111/j.16000587.2010.06390.x.

McEwan, R.W., T.F. Hutchinson, R.P. Long, D.R. Ford, and B.C. McCarthy. 2007. Temporal and spatial patterns in fire occurrence during the establishment of mixed-oak forests in eastern North America. Journal of Vegetation Science 18: 655-664. https://doi.org/10.1111/j.1654-1103.2007.tb02579.x.

McEwan, R.W., N. Pederson, A. Cooper, J. Taylor, R. Watts, and A. Hruska. 2014. Fire and gap dynamics over 300 years in an old-growth temperate forest. Applied Vegetation Science 17: 312-322. https://doi.org/10.1111/avsc.12060.

McNab, W.H., D.T. Cleland, J.A. Freeouf, G.J. Keys, G.J. Nowacki, and C.A. Carpenter, compilers. 2007. Description of ecological subregions: sections of the conterminous United States. USDA Forest Service General Technical Report WO-
76B. Washington, D.C.: US Department of Agriculture, Forest Service. https:// doi.org/10.2737/WO-GTR-76B.

Moser, W.K., M. Hansen, W.H. McWilliams, and R.M. Sheffield. 2007. Shortleaf pine composition and structure in the United States. In Shortleaf pine restoration and ecology in the Ozarks: proceedings of a symposium. USDA Forest Service General Technical Report NRS-P-15, ed. J.M. Kabrick, D.C. Dey, and D. Gwaze, 19-27. Newtown Square: USDA Forest Service, Northern Research Station.

Nowacki, G.J., and M.D. Abrams. 2008. The demise of fire and "mesophication" of forests in the eastern United States. Bioscience 58: 123-138. https://doi.org/1 $0.1641 /$ B580207.

Olson, M.G., and E.K. Olson. 2016. Multiple treatments yield early success in a shortleaf pine woodland restoration project in the Missouri Ozarks. In Proceedings of the 18th Biennial Southern Silvicultural Research Conference. USDA Forest Service General Technical Report SRS-212, ed. C.J. Schweitzer, W.K. Clatterbuck, and C.M. Oswalt, 444-453. Asheville: USDA Forest Service, Southern Research Station.

Shumway, D.L., M.D. Abrams, and C.M. Ruffner. 2001. A 400-year history of fire and oak recruitment in an old-growth oak forest in western Maryland, USA. Canadian Journal of Forest Research 31: 1437-1443. https://doi.org/10.1139/x01-079.

South, D.B., and R.A. Harper. 2016. A decline in timberland continues for several Southern yellow pines. Journal of Forestry 114: 116-124. https://doi.org/10.5 849/jof.15-006.

Stambaugh, M.C., R.P. Guyette, and D.C. Dey. 2007. What fire frequency is appropriate for shortleaf pine regeneration and survival? In Shortleaf pine restoration and ecology in the Ozarks: proceedings of a symposium. USDA Forest Service General Technical Report NRS-P-15, ed. J.M. Kabrick, D.C. Dey, and D. Gwaze, 121-128. Newtown Square: USDA Forest Service, Northern Research Station.

Stambaugh, M.C., J.M. Marschall, E.R. Abadir, B.C. Jones, P.H. Brose, D.C. Dey, and R.P. Guyette. 2018. Wave of fire: an anthropogenic signal in historical fire regimes across central Pennsylvania, USA. Ecosphere 9 (5): e02222. https://doi. org/10.1002/ecs2.2222.

Stambaugh, M.C., and R.-M. Muzika. 2007. Successional trends of six mature shortleaf pine forests in Missouri. In Shortleaf pine restoration and ecology in the Ozarks: proceedings of a symposium. USDA Forest Service General Technical Report NRS-P-15, ed. J.M. Kabrick, D.C. Dey, and D. Gwaze, 59-67. Newtown Square: USDA Forest Service, Northern Research Station.

Stambaugh, M.C., J.M. Varner, R.F. Noss, D.C. Dey, N.L. Christensen, R.F. Baldwin, R.P. Guyette, B.B. Hanbern, C.A. Harper, S.G. Lindblom, and T.A. Waldrop. 2015. Clarifying the role of fire in the deciduous forests of eastern North America: reply to Matlack. Conservation Biology 29: 942-946. https://doi.org/10.1111/cobi.12473.

Stokes, M.A., and T.L. Smiley. 1968. An introduction to tree-ring dating. Tucson: University of Arizona Press.

Sutherland, E.K. 1997. History of fire in a southern Ohio second-growth mixedoak forest. In 11th Central Hardwood Forest conference proceedings. USDA Forest Service General Technical Report NC-188, ed. S.G. Pallardy, R.A. Cecich, H. G. Garrett, and P.S. Johnson, 172-183. St. Paul: USDA Forest Service, North Central Forest Experiment Station.

Swetnam, T.W., and C.H. Baisan. 1996. Historic fire regime patterns in the southwestern United States since AD 1700. In: Fire effects in Southwestern forests: proceedings of the second La Mesa fire symposium. USDA Forest Service General Technical Report RM-286. Technical editing by C.D. Allen. 11-32. Fort Collins: USDA Forest Service, Rocky Mountain Forest and Range Experiment Station. doi: https://doi.org/10.2737/RM-GTR-286

Van Horne, M.L., and P.Z. Fulé. 2006. Comparing methods of reconstructing fire history using fire scars in a southwestern United States ponderosa pine forest. Canadian Journal of Forest Research 36: 855-867. https:/doi.org/10.1139/x05-289.

Waldrop, T.A., and P.H. Brose. 1999. A comparison of fire intensity levels for stand replacement of Table Mountain pine (Pinus pungens Lamb.). Forest Ecology and Management 113: 155-166. https://doi.org/10.1016/S0378-112 7(98)00422-8.

Williams, M. 1989. Americans and their forests: a historical geography. Cambridge: Cambridge University Press.

Yaussy, D.A., and EK Sutherland. 1994. Fire history in the Ohio River Valley and its relation to climate. In: Proceedings of the 12th conference on fire and forest meteorology: 26-28 October 1993, Jekyll Island, Georgia, USA. Society of American Foresters 94(2): 777-786.

\section{Publisher's Note}

Springer Nature remains neutral with regard to jurisdictional claims in published maps and institutional affiliations. 